\title{
Article \\ Risk of Secondary Household Transmission of COVID-19 from Health Care Workers in a Hospital in Spain
}

\author{
Miren Remón-Berrade ${ }^{1}$, Sara Guillen-Aguinaga ${ }^{2,3}{ }^{\circledR}$, Isabel Sarrate-Adot ${ }^{1}$, Maria Pilar Garcia-Garcia ${ }^{1}$, \\ Maria del Carmen Lerga-Berruezo ${ }^{1}$, Laura Guillen-Aguinaga ${ }^{4}(\mathbb{D})$ and Francisco Guillen-Grima ${ }^{1,3,5, *(1)}$
}

1 Department of Preventive Medicine, Clínica Universidad de Navarra, 31008 Pamplona, Navarra, Spain; mremon@unav.es (M.R.-B.); misarrate@unav.es (I.S.-A.); mpgar@unav.es (M.P.G.-G.); mlergab@unav.edu (M.d.C.L.-B.)

2 Azpilagaña Health Center, Navarra Health Service, 31006 Pamplona, Navarra, Spain; sguillen.4@alumni.unav.es

3 Department of Health Sciences, Public University of Navarra (UPNA), 31008 Pamplona, Navarra, Spain

4 Department of Nursing, Clínica Universidad de Navarra, 31008 Pamplona, Navarra, Spain; lguillen@unav.es

5 Instituto de Investigación Sanitaria de Navarra (IdiSNA), 31008 Pamplona, Navarra, Spain

* Correspondence: frguillen@unav.es; Tel.: +34-948-296-384

check for updates

Citation: Remón-Berrade, M.; Guillen-Aguinaga, S.; Sarrate-Adot,

I.; Garcia-Garcia, M.P.;

Lerga-Berruezo, M.d.C.;

Guillen-Aguinaga, L.; Guillen-Grima,

F. Risk of Secondary Household

Transmission of COVID-19 from

Health Care Workers in a Hospital in

Spain. Epidemiologia 2022, 3, 1-10.

https://doi.org/10.3390/

epidemiologia3010001

Academic Editor:

Alberto Arnedo-Pena

Received: 13 November 2021

Accepted: 23 December 2021

Published: 27 December 2021

Publisher's Note: MDPI stays neutral with regard to jurisdictional claims in published maps and institutional affiliations.

Copyright: (C) 2021 by the authors. Licensee MDPI, Basel, Switzerland. This article is an open access article distributed under the terms and conditions of the Creative Commons Attribution (CC BY) license (https:// creativecommons.org/licenses/by/ $4.0 /)$.

\begin{abstract}
Background: Hospital health care workers are at high risk of developing COVID-19 and transmitting the disease to their family upon returning home; the aim here is to estimate the secondary attack rate of COVID-19 in household contacts of health care workers and their transmission risk factors. Material and Methods: COVID-19 cases in the health care workers of an academic hospital in Pamplona, Spain, from 2 March to 26 May 2020, were followed up. The secondary attack rate (SAR) was estimated from cases in household contacts of index cases and their risk factors by Poisson regression. Results: 89 index cases were studied from 99 notified cases in health care workers $(89.0 \%)$, excluding secondary cases or those who lived alone. Forty-six secondary cases confirmed by the laboratory were found among 326 household contacts, a secondary attack rate of $14.11 \%$ (95\% CI 10.75-18.31), and 33 household contacts with acute infection symptoms without microbiologic confirmation $10.12 \%$ (95\% CI 7.30-13.87). Considering all the cases, the secondary attack rate was 27.3 (95\% CI 22.75-32.38). Risk factors were the gender and profession of the index case, the number of people living in the household, and the number of persons per bedroom. When the index case health worker used a single room, it had a protective effect, with an incidence rate ratio (IRR) of 0.493 (95\% CI 0.246-0.985); Conclusions: The secondary attack rate found among household contacts of health care workers is high. The preventive isolation of health care workers in individual rooms in their house may reduce the transmission in their families.
\end{abstract}

Keywords: COVID-19; secondary attack rate; risk-factors; household contacts; health care workers

\section{Introduction}

COVID-19 is a disease caused by SARS-CoV-2. It was first reported in Wuhan, China, in December 2019 and then spread across continents. In Spain, the first case was on 31 January, from a German tourist on the Canary Island of La Gomera, and the second on 9 February, from a British tourist in Palma de Mallorca, Balearic Islands. The incubation is between 2 and 14 days. Some patients may be asymptomatic, some may develop mild symptoms, and some may develop severe pneumonia [1].

SARS-CoV-2 is highly contagious, and numerous studies have been conducted to learn the secondary attack rate in families in which a member develops COVID-19 [2,3]. According to $\mathrm{WHO}$, health care workers (HCW) are defined as "all persons who perform actions whose primary intention is to improve health" $[4,5]$. Health care workers include physicians, nurses, nursing assistants, orderlies, support staff (cleaning, laundry, kitchen, maintenance, and security), and hospital managers [4]. Health care workers are at a high 
risk of developing COVID-19 and may even die from their occupation [6,7]. Numerous studies have been conducted on the risk of infection in healthcare workers. Nearly $25 \%$ of health care workers said they were reluctant to work during a pandemic because of the risk of transmitting the disease to their families [8]. Health care workers have experimented with anxiety, high levels of psychological distress, and mental disorders, such as depression, generalized anxiety disorder (GAD), and posttraumatic stress disorder (PTSD), during the pandemic $[9,10]$. This can lead to burnout in health care workers [11]. The stress level is higher in nurses than in other health care workers [12]. One of the causes was concern about transmitting the disease to their family upon returning home [13], especially when they have vulnerable family members [14]. Despite the importance of this fact, few publications deal with the risk of transmission from healthcare workers to their families [15-17].

Objective: This study aims to estimate in an academic hospital in Navarra (Spain) the secondary attack rate of COVID-19 in household contacts of health care workers and their transmission risk factors.

\section{Materials and Methods}

As part of the epidemiological surveillance of COVID-19, the Department of Preventive Medicine of the Clinica Universidad de Navarra in Pamplona studied the cases of COVID-19 among health care workers. A retrospective cohort was also made with family contacts of health care workers.

When a case was reported in health care workers, an epidemiological survey was completed. Follow-up of patients and their contacts were performed by contact tracers using the COVID-19 protocols approved by the Ministry of Health [18]. These protocols involved the clinical investigation of close contacts and their quarantine. In the first $24 \mathrm{~h}$, PCR or antigen testing was performed if reagents were available. Between 2 March and 26 May 2020, during the first wave of the pandemic of COVID-19 in Pamplona, ninety-nine cases of COVID-19 were diagnosed among health care workers at Clinica Universidad de Navarra. We computed the primary attack rate among health care workers at Clinica Universidad de Navarra. Health care workers were divided into five groups: physicians, nurses, nursing assistants, orderlies, and others.

All subjects provided oral informed consent to the processing of the telephone interview data for research purposes. The research was conducted in compliance with the principles of the Helsinki Declaration as part of the mandatory epidemiological surveillance of COVID-19 among health care workers. A telephone survey was used to follow up on the evolution of family contacts. We collected demographic information, housing conditions, the number of people living in the dwelling, and whether the health care workers had taken extraordinary preventive measures before being diagnosed.

Primary attack rates (AR) among health care workers (HCW) and secondary attack rates (SAR) among the household contacts of affected workers have been calculated.

$\mathrm{AR}(\%)=$ Number of new cases of COVID-19 in HCW $/$ Total number of HCW at risk $\times 100$

SAR $(\%)=$ Number of new cases among contacts $/$ Total number of contacts at risk $\times 100$

Odds ratios and 95\% confidence intervals were calculated with IBM SPSS version 22. Poisson regression was performed to relate the different exposures to the number of secondary cases by calculating the univariate incidence rate ratio with Stata version 13.

\section{Results}

The maximum number of cases among health care workers occurred in the week of 16 March (Figure 1). On 12 March 2020, the hospital management imposed all staff's mandatory face masks. After that, there was an abrupt decrease in the number of cases. 


\section{Epidemic Curve}

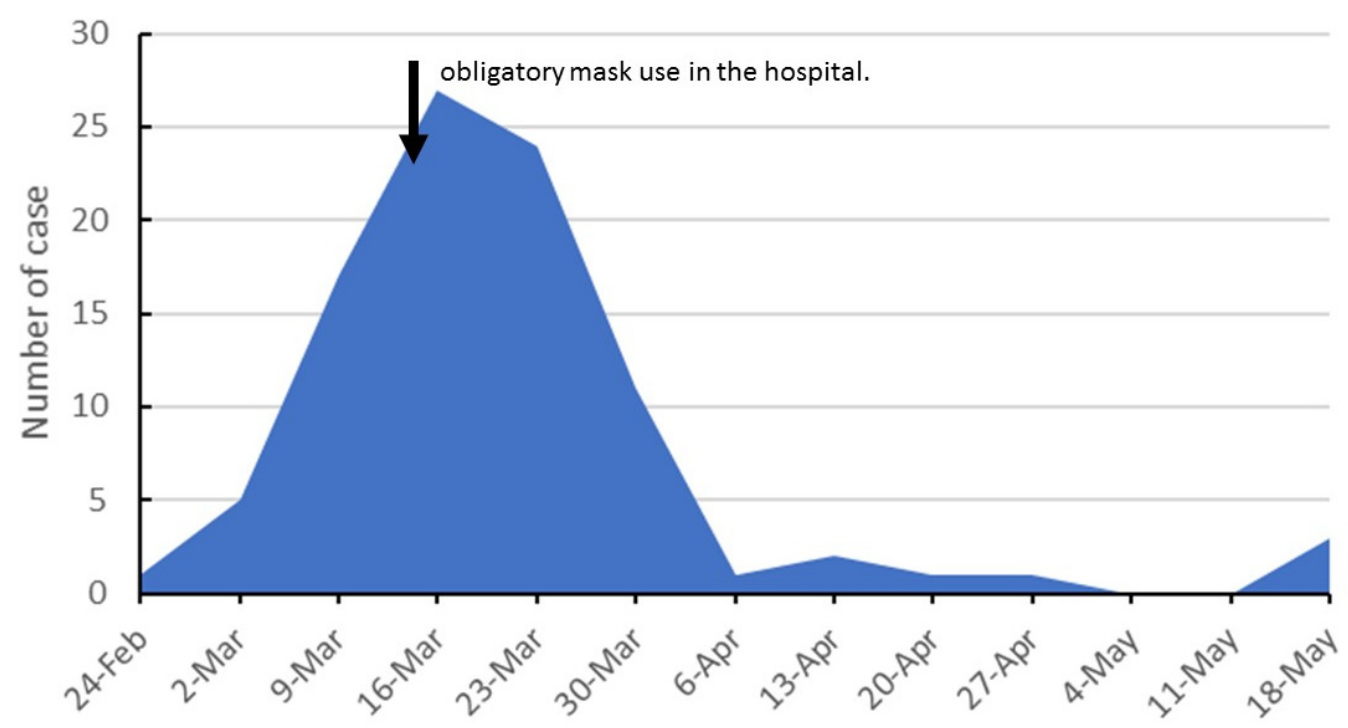

Figure 1. Epidemic Curve of cases in Health Care workers February-May 2020.

The primary attack rate among health care workers was 4.51\% (95\% CI 3.72-5.47). The most affected groups were hospital orderlies, with an AR of $15.38 \%$ and an OR $=18.73 \%$ $(95 \% \mathrm{CI}=3.63-96.73)$, followed by nurses and nursing assistants with attack rates of $7.15 \%$ and $6.62 \%$. The least affected group was the cleaning, laundry, and kitchen staff, with an AR of $0.96 \%$.

A total of 99 workers had COVID-19. Five workers could not be reached after five successive telephone calls (they were on holiday or hospitalized with COVID-19). Among the remaining 94 health care workers, five were excluded as index cases to estimate secondary attack rates (SAR) because they lived alone or were secondary cases.

In the secondary attack rate study, 89 index cases were included, representing 89.9\% of the notified cases. Forty-six secondary patients confirmed by the laboratory were found among 326 household contacts. This means a secondary attack rate of $14.11 \%$ (95\% CI 10.75-18.31). In addition to the laboratory-confirmed cases, 33 household contacts with symptoms classified as secondary symptoms only made up $10.12 \%$ (95\% CI 7.30-13.87). Considering all the cases, the secondary attack rate was 27.3 (95\% CI 22.75-32.38).

Secondary cases are concentrated in some families. Thus, in $11 \%$ of the households, more than $50 \%$ of the cases of secondary transmission are concentrated. (Table S1). In the same way, $25 \%$ of the families account for $80 \%$ of the cases of secondary transmission (Figure 2). 


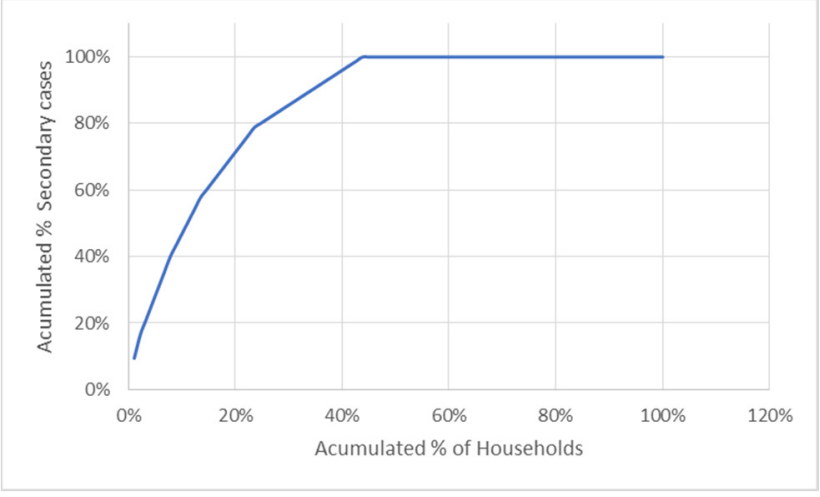

(a)

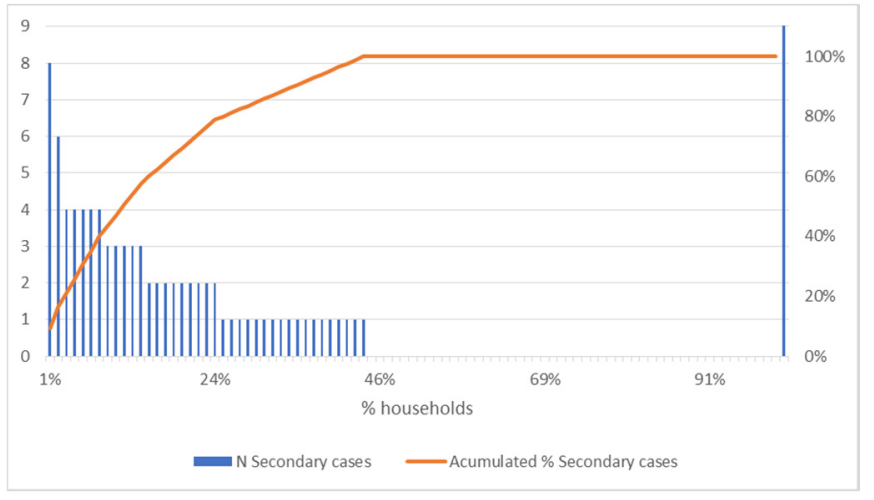

(b)

Figure 2. Distribution of cases by households: (a) Secondary cases by households (b) Pareto's chart of secondary cases of COVID-19 by households.

\subsection{Index Cases Characteristic and Risk of Secondary Transmission}

The univariate Poisson regression shows that secondary transmission was more frequent in males and the 30-39 age group with incidence rate ratios of 1.351 and 2.054. The professional groups with the highest risk of having secondary infections at home were physicians with an IRR of 5.777 and orderlies with an IRR of 4.800 (Tables 1 and 2).

Table 1. Attack rate in health care workers.

\begin{tabular}{ccccc}
\hline Profession & $\boldsymbol{n}$ & AR & OR & $\mathbf{9 5 \% ~ C I ~}$ \\
\hline Cleaning, laundry, and Kitchen staff & 208 & $0.96 \%$ & 1 & \\
Physicians & 475 & $4.00 \%$ & 4.29 & $0.99-18.60$ \\
Nurses & 657 & $7.15 \%$ & 7.94 & $1.91-32.96$ \\
Nursing assistant & 298 & $6.04 \%$ & 6.62 & $1.52-28.85$ \\
Orderlies & 39 & $15.38 \%$ & 18.73 & $3.63-96.73$ \\
Other professionals & 495 & $1.21 \%$ & 1.26 & $0.25-6.31$ \\
\hline
\end{tabular}

Table 2. Univariate Exact Poisson regression of secondary transmission by personal characteristics of index cases.

\begin{tabular}{ccccccc}
\hline Variable & Case & No Case & Total & IRR & $\mathbf{9 5 \%}$ CI & $p$ \\
\hline Age & & & & 0.993 & $0.975-1.012$ & 0.492 \\
\hline Age Group & & & & & & \\
$18-29$ & 19 & 31 & 50 & 1.180 & $0.591-2.353$ & 0.638 \\
$30-39$ & 23 & 23 & 46 & 2.054 & $1.056-3.990$ & 0.034 \\
$40-49$ & 29 & 126 & 155 & 1.380 & $0.729-2.613$ & 0.321 \\
$50-62$ & 14 & 61 & 75 & 1 & & \\
Sex & & & & & & \\
Female & 10 & 79 & 89 & 1 & & \\
Male & 75 & 162 & 237 & 1.351 & $1.060-1.725$ & 0.015 \\
\hline $\begin{array}{c}\text { Occupation } \\
\text { other professionals }\end{array}$ & 2 & 39 & 41 & 1 & & - \\
Physician & 26 & 89 & 115 & 5.777 & $1.371-24.342$ & 0.017 \\
nurse & 36 & 82 & 118 & 3.512 & $0.845-14.586$ & 0.084 \\
auxiliary & 15 & 29 & 44 & 3.529 & $0.807-15.433$ & 0.094 \\
orderlies & 6 & 2 & 8 & 4.800 & $0.968-23.781$ & 0.055 \\
\hline
\end{tabular}




\subsection{Household and Risk of Secondary Transmission}

In a univariate Poisson regression model, households with four or more members have a higher risk of having secondary cases. The highest risk appears in those households with more than five people with an incidence rate ratio of 7.064 (Table 3). The number of bedrooms and bathrooms in the house is not associated with having secondary cases. When the number of persons per bedroom was higher than 1.5, the incidence rate ratio of having COVID-19 cases was 5.167. The number of persons per bathroom has a lower influence on secondary transmission.

Table 3. Univariate Exact Poisson regression of secondary transmission by household characteristics of index cases.

\begin{tabular}{|c|c|c|c|c|c|c|}
\hline Variable & Case & No Case & Total & IRR & $95 \%$ CI & $p$ \\
\hline \multicolumn{7}{|c|}{$n$. Household members } \\
\hline 2 & 6 & 13 & 19 & 1 & & \\
\hline 3 & 9 & 27 & 36 & 1.583 & $0.563-4.448$ & 0.383 \\
\hline 4 & 21 & 51 & 72 & 2.770 & $1.118-6.865$ & 0.028 \\
\hline 5 & 20 & 40 & 60 & 1.965 & $1.696-10.513$ & 0.002 \\
\hline$>5$ & 29 & 110 & 139 & 7.064 & 2.932-17.014 & $<0.001$ \\
\hline \multicolumn{7}{|l|}{ n. Bedrooms } \\
\hline 2 & 8 & 13 & 21 & 1 & & \\
\hline 3 & 32 & 53 & 85 & 2.133 & $0.983-4.629$ & 0.055 \\
\hline 4 & 22 & 57 & 79 & 1.760 & $0.783-3.953$ & 0.171 \\
\hline$>4$ & 15 & 113 & 128 & 2.000 & $0.847-4.717$ & 0.113 \\
\hline n. Bathrooms & & & & 0.973 & $0.902-1.050$ & 0.486 \\
\hline \multicolumn{7}{|c|}{ n. Persons/Bedroom } \\
\hline$<1$ & 8 & 13 & 21 & 1 & & \\
\hline 1 & 32 & 53 & 85 & 2.213 & $0.908-5.396$ & 0.080 \\
\hline $1-1.499$ & 22 & 57 & 79 & 2.125 & $0.825-5.477$ & 0.119 \\
\hline$\geq 1.5$ & 15 & 113 & 128 & 5.167 & $2.156-12.383$ & $<0.001$ \\
\hline \multicolumn{7}{|c|}{ n. persons/bathroom } \\
\hline$>1$ & 9 & 62 & & 1 & & \\
\hline $1-2$ & 44 & 133 & & 2.095 & $1.022-4.292$ & 0.043 \\
\hline$>2$ & 24 & 41 & & 1.368 & $1.627-7.529$ & 0.001 \\
\hline
\end{tabular}

In Table 4, we present the hygienic measures taken by health care workers at home. The IRR of having secondary cases of COVID-19 was lower when using masks at home and gloves (IRR =0.607; 95\% CI 0.362-0.988), cleaning surfaces with disinfectant, and having individual bedrooms. Using individual or disposable tableware, having a separate bathroom, and washing clothes separately were not associated with having secondary cases of COVID-19 in the household. 
Table 4. Univariate Exact Poisson regression of secondary transmission according to preventive measures taken by health workers to prevent infection at home.

\begin{tabular}{|c|c|c|c|c|c|c|}
\hline Variable & Case & No Case & Total & IRR & $95 \%$ CI & $p$ \\
\hline \multicolumn{7}{|c|}{ Wearing a mask at home } \\
\hline No & 22 & 42 & 64 & 1 & & \\
\hline Yes & 63 & 199 & 262 & 0.534 & $0.329-0.869$ & 0.011 \\
\hline \multicolumn{7}{|c|}{ Wearing Gloves } \\
\hline No & 61 & 134 & 195 & 1 & & \\
\hline Yes & 24 & 107 & 131 & 0.607 & $0.362-0.988$ & 0.044 \\
\hline \multicolumn{7}{|c|}{ Hand washing } \\
\hline No & 26 & 55 & 81 & 1 & - & - \\
\hline Yes & 59 & 186 & 245 & 0.616 & $0.382-1.018$ & 0.059 \\
\hline \multicolumn{7}{|c|}{ Wash clothes separately } \\
\hline No & 33 & 74 & 107 & 1 & & \\
\hline Yes & 52 & 167 & 219 & 0.650 & $0.413-1.039$ & 0.0723 \\
\hline \multicolumn{7}{|c|}{ Individual or disposable tableware } \\
\hline No & 29 & 47 & 76 & 1 & - & - \\
\hline Yes & 56 & 194 & 250 & 0.456 & $0.286-0.740$ & 0.002 \\
\hline \multicolumn{7}{|c|}{ Cleaning surfaces with disinfectant } \\
\hline No & 33 & 59 & 92 & 1 & - & - \\
\hline Yes & 52 & 182 & 234 & 0.487 & $0.315-0.753$ & 0.001 \\
\hline \multicolumn{7}{|c|}{ Individual Bedroom } \\
\hline No & 19 & 34 & 53 & 1 & - & - \\
\hline Yes & 66 & 207 & 273 & 0.490 & $0.294-0.816$ & 0.001 \\
\hline \multicolumn{7}{|c|}{ Individual Bathroom } \\
\hline No & 19 & 34 & 53 & 1 & - & - \\
\hline Yes & 66 & 207 & 273 & 0.650 & $0.413-1.039$ & 0.0723 \\
\hline
\end{tabular}

In the multivariate Poisson model, we adjusted by age, sex, profession, and onset date. We computed Poisson regression models only with those variables that were significant in the univariate model. Wearing a mask and gloves at home, using individual or disposable tableware, cleaning surfaces with disinfectant, and having a single room all contribute to reducing the risk of secondary transmission (Table 5).

Table 5. Multivariate Exact Poisson regressions of secondary transmission according to preventive measures taken by health workers to prevent infection at home.

\begin{tabular}{cccc}
\hline Variable & IRR * & $\mathbf{9 5 \% ~ C I ~}$ & $p$ \\
\hline Wearing a mask at home & 0.540 & $0.311-0.937$ & 0.028 \\
Wearing Gloves at home & 0.599 & $0.367-0.977$ & 0.040 \\
individual or disposable tableware & 0.517 & $0.313-0.855$ & 0.010 \\
Cleaning surfaces with disinfectant & 0.510 & $0.312-0.833$ & 0.007 \\
Individual Bedroom & 0.453 & $0.268-0.764$ & 0.003 \\
\hline
\end{tabular}

* Each variable is adjusted by age, sex, profession, date of onset.

\section{Discussion}

A meta-analysis found that the prevalence of COVID-19 among health care workers was $10.1 \%$ but was higher in the United States with $17.1 \%$ [19]. A study found that $19.4 \%$ of health care workers in New York were infected with COVID-19. In a hospital in Switzerland, the seroprevalence among health care workers was $10.0 \%[20,21]$. Nurses are one of the most affected groups among healthcare workers. A meta-analysis found that the prevalence of anti-COVID-19 antibodies was 10.3\% among nurses in Europe [22]. In our study, the risk was higher in nurses than in physicians. This differs from another meta-analysis that found that physicians were more at risk than nurses [23]. Our primary attack rate, $7.79 \%$, 
was lower than the $9.5 \%$ of a Swiss hospital [21]. It was higher than that of the metaanalysis mentioned above, 6.5\% [23]. In our study, the group with a higher attack rate was orderly with $18.73 \%$, while in the Swiss study, the group with a higher prevalence was trainees/students [21].

The reference group was the cleaning, kitchen, and laundry staff, most of whom were not in contact with patients. Although some of them did not, the cleaning staff in the ICU and on the floor with COVID-19 patients could contact COVID-19 patient rooms. However, this personnel used all the personal protective equipment and available ultraviolet disinfection systems.

Similarly, the "other professionals" group included administrative, managerial, maintenance (electricians, computer technicians, plumbers, carpenters), radiology technicians, laboratory technicians, and CAT technicians. This group could also have been considered baseline because most of them were not in contact with patients, although they might have some contact with patients on occasion, such as making a repair in a room or taking a chest X-ray of a patient with COVID-19.

Table 1 shows that the attack rate of the other group is very similar to that of the cleaning, kitchen, and laundry group. It would have been possible to merge the two groups, but we felt it was more informative to present them separately.

There is evidence that COVID-19 transmission and secondary transmission occur in clusters [24-26], sometimes due to super-spreading events [25]. We have found that a small proportion of health care workers was responsible for most of the secondary transmission.

Transmission is frequent in households in the general population. One meta-analysis found that families have the highest transmission rates, with a pooled secondary attack rate of $21.1 \%$ [3]. In Spain, the secondary attack rate in households was $38.7 \%$ [27].

The rate found among the families of healthcare personnel in our study is like that of the meta-analysis in the general population but substantially lower than the Spanish figures, indicating that the preventive measures taken by healthcare professionals have been partially effective. We detected a secondary attack rate of $27.3 \%$ in our study. In Spain, a survey among health care workers' children found a secondary attack rate of 43.7\% [28]. In comparison, studies performed among health care workers' families in Amsterdam and China detected secondary attack rates of $10.98 \%, 18.8 \%$, and $23.3 \%$ [29-31].

Table 3 shows in the univariate Poisson regression that the number of cases is related to the number of people living in the house and the number of bedrooms and bathrooms. The number of bedrooms and bathrooms in the dwelling is related to the number of people. The observations must be independent in Poisson regression, which is not the case here. Table 3 shows that the higher the number of people in a household, the higher the number of cases predicted by the model. This result shows the nonindependence of the cases, and so one should be careful when interpreting Tables 2 and 4 . It is necessary to protect both the health care workers and their families [32]. Because of the possibility of infection during the incubation period, the measures to be effective must be permanent and heavy [8]. Our study, despite its limitations, sheds light on the most effective measures: wearing a mask and gloves at home, using individual or disposable tableware, cleaning surfaces with disinfectant, and having a single room.

During the pandemic, some hotels provided housing for health care workers [33-39]. In one survey, $77 \%$ of health care workers stated that they could not isolate themselves in their household [40]. Our findings suggest that this measure may be helpful in future pandemic waves to protect the families of health care workers who do not have the space in their homes to have an individual room for the HCW.

Supplementary Materials: The following are available online at https:/ /www.mdpi.com/article/10 .3390/epidemiologia3010001/s1, Table S1: Distribution of families and secondary cases.

Author Contributions: Conceptualization, F.G.-G., M.R.-B., I.S.-A., M.d.C.L.-B. and M.P.G.-G.; methodology F.G.-G., M.R.-B., I.S.-A., M.d.C.L.-B. and M.P.G.-G.; formal analysis, S.G.-A., F.G.-G. and L.G.-A.; investigation, M.R.-B., I.S.-A., M.d.C.L.-B., M.P.G.-G., S.G.-A., F.G.-G. and L.G.-A.; data cura- 
tion, S.G.-A., F.G.-G. and L.G.-A.; writing-original draft preparation, S.G.-A., F.G.-G. and L.G.-A.; writing-review and editing, M.R.-B., I.S.-A., M.d.C.L.-B., M.P.G.-G., S.G.-A., F.G.-G. and L.G.-A.; visualization, S.G.-A.; supervision, F.G.-G. All authors have read and agreed to the published version of the manuscript.

Funding: This research received no external funding.

Institutional Review Board Statement: The study was conducted according to the guidelines of the Declaration of Helsinki. The study was part of the routine compulsory epidemiologic surveillance of the cases of COVID-19 among health care workers, which is exempted from Ethics Review Board approval's protocol according to the Spanish legislation, including the General Law of Health, the Law of Cohesion and Quality of the National System of Health, and the Law General of Public Health [41-43], Law 2/2021, of 29 March, on urgent measures of prevention, containment and coordination to address the health crisis caused by the COVID-19 [44] and the Epidemiological surveillance [45] and COVID-19 regulations [46,47].

Informed Consent Statement: Informed consent was obtained from all subjects involved in the study.

Data Availability Statement: The datasets generated for this study are unavailable due to the data protection law.

Conflicts of Interest: The authors declare no conflict of interest.

\section{References}

1. Tadj, A.; Lahbib, S.S.M. Our Overall Current Knowledge of COVID 19: An Overview. Microbes Infect. Chemother. 2021,1 , e1262. [CrossRef]

2. Angulo-Bazán, Y.; Solis-Sánchez, G.; Cardenas, F.; Jorge, A.; Acosta, J.; Cabezas, C. Household transmission of SARS-CoV-2 (COVID-19) in Lima, Peru. Cad. Saude Publica 2021, 37, e00238720. [CrossRef]

3. Thompson, H.A.; Mousa, A.; Dighe, A.; Fu, H.; Arnedo-Pena, A.; Barrett, P.; Bellido-Blasco, J.; Bi, Q.; Caputi, A.; Chaw, L.; et al. Severe Acute Respiratory Syndrome Coronavirus 2 (SARS-CoV-2) Setting-specific Transmission Rates: A Systematic Review and Meta-analysis. Clin. Infect. Dis. 2021, 73, e754-e764. [CrossRef]

4. WHO. Health Workforce Requirements for Universal Health Coverage and the Sustainable Development Goals; WHO: Geneva, Switzerland, 2016; pp. 1-40.

5. WHO. Health Workers: A Global Profile; World Health Organization: Geneva, Switzerland, 2006.

6. Viego, V.; Geri, M.; Castiglia, J.; Jouglard, E. Incubation period and serial interval of COVID-19 in a chain of infections in Bahia Blanca (Argentina). Cien. Saude Colet. 2020, 25, 3503-3510. [CrossRef] [PubMed]

7. Kalra, A.; Michos, E.D.; Chinnaiyan, K.M. COVID-19 and the healthcare workers. Eur. Heart J. 2020, 41, 2936-2937. [CrossRef]

8. McConnell, D. Balancing the duty to treat with the duty to family in the context of the COVID-19 pandemic. J. Med. Ethics 2020, 46, 360-363. [CrossRef]

9. Wilson, W.; Raj, J.P.; Rao, S.; Ghiya, M.; Nedungalaparambil, N.M.; Mundra, H.; Mathew, R. Prevalence and Predictors of Stress, anxiety, and Depression among Healthcare Workers Managing COVID-19 Pandemic in India: A Nationwide Observational Study. Indian J. Psychol. Med. 2020, 42, 353-358. [CrossRef] [PubMed]

10. Kumar, M.; Mohindra, R.; Sharma, K.; Soni, R.K.; Rana, K.; Singh, S.M. The impact of working in a COVID hospital on sexual functioning in male nurses: A study from North India. Ind. Psychiatry J. 2021, 30, 187-190. [CrossRef]

11. Farahat, S.A.; Amin, O.R.; Hamdy, H.S.; Fouad, M.M. The impact of work-related stress on the cognition domain of executive functioning of health care workers during the COVID-19 pandemic. Int. Arch. Occup. Environ. Health 2021, 1-12. [CrossRef]

12. Nissan, D.; Weiss, G.; Siman-Tov, M.; Spitz, A.; Bodas, M.; Shenhar, G.; Adini, B. Differences in levels of psychological distress, perceived safety, trust, and efficacy amongst hospital personnel during the COVID-19 pandemic. Res. Nurs. Health 2021, 44, 776-786. [CrossRef]

13. Lake, E.T.; Narva, A.M.; Holland, S.; Smith, J.G.; Cramer, E.; Rosenbaum, K.E.F.; French, R.; Clark, R.R.S.; Rogowski, J.A. Hospital nurses' moral distress and mental health during COVID-19. J. Adv. Nurs. 2021. [CrossRef]

14. Brand, M.W.; Wiskur, B.; Rojas, J.I. Assessing fear of COVID-19 at an academic medical center. J. Emerg. Manag. 2020, 18, 91-98. [CrossRef] [PubMed]

15. Karlsson, U.; Fraenkel, C.-J. COVID-19: Risks to Healthcare Workers and Their Families. Available online: https: / / www.cebm.net/wp-content/uploads/2020/04/Are-interventions-such-as-social-distancing-effective-at-reducing-therisk-of-asymptomatic-healthcare-workers-transmitting-COVID-final.pdf (accessed on 13 November 2021).

16. Shah, A.S.V.; Wood, R.; Gribben, C.; Caldwell, D.; Bishop, J.; Weir, A.; Kennedy, S.; Reid, M.; Smith-Palmer, A.; Goldberg, D.; et al. Risk of hospital admission with coronavirus disease 2019 in healthcare workers and their households: Nationwide linkage cohort study. BMJ 2020, 371, m3582. [CrossRef] 
17. Quental, K.N.; Leite, A.L.; de Oliveira, Z.N.P.; de Sousa Tavares, L.V.; de Sousa Tavares, W.G.; Pinheiro, E.F.; Lacsina, J.R.; DeSouza-Vieira, T.; Silva, J.B.N.F. SARS-CoV-2 co-infection with dengue virus in Brazil: A potential case of viral transmission by a health care provider to household members. Travel Med. Infect. Dis. 2021, 40, 101975. [CrossRef]

18. Ministerio de Sanidad y Consumo. Estrategia de Detección Precoz, Vigilancia y Control de COVID-19. [Strategy for Early Detection, Surveillance and Control of COVID-19]; Ministerio de Sanidad: Madrid, Spain, 2020.

19. Sahu, A.K.; Amrithanand, V.T.; Mathew, R.; Aggarwal, P.; Nayer, J.; Bhoi, S. COVID-19 in health care workers-A systematic review and meta-analysis. Am. J. Emerg. Med. 2020, 38, 1727-1731. [CrossRef] [PubMed]

20. Stock, A.D.; Bader, E.R.; Cezayirli, P.; Inocencio, J.; Chalmers, S.A.; Yassari, R.; Yanamadala, V.; Eskandar, E. COVID-19 Infection among Healthcare Workers: Serological Findings Supporting Routine Testing. Front. Med. 2020, 7, 471. [CrossRef]

21. Meylan, S.; Dafni, U.; Lamoth, F.; Tsourti, Z.; Lobritz, M.A.; Regina, J.; Bressin, P.; Senn, L.; Grandbastien, B.; Andre, C.; et al SARS-CoV-2 seroprevalence in healthcare workers of a Swiss tertiary care centre at the end of the first wave: A cross-sectional study. BMJ Open 2021, 11, e049232. [CrossRef]

22. He, S.; Hecimovic, A.; Matijasevic, V.; Mai, H.T.; Heslop, L.; Foster, J.; Alexander, K.E.; Pal, N.; Alexandrou, E.; Davidson, P.M.; et al. Prevalence of SARS-CoV-2 antibodies among nurses: A systematic review and meta-analysis. J. Clin. Nurs. 2021. [CrossRef] [PubMed]

23. Riccò, M.; Gualerzi, G.; Ranzieri, S.; Peruzzi, S.; Valente, M.; Marchesi, F.; Bragazzi, N.L.; Signorelli, C. Occurrence of SARS-CoV-2 infection among healthcare personnel: Results from an early systematic review and meta-analysis. Acta Biomed. 2021, 92, e2021311. [CrossRef]

24. Madewell, Z.J.; Yang, Y.; Longini, I.M.; Halloran, M.E.; Dean, N.E. Household Transmission of SARS-CoV-2. JAMA Netw. Open 2020, 3, e2031756. [CrossRef]

25. Huang, P.-Y.; Wu, T.-S.; Cheng, C.-W.; Chen, C.-J.; Huang, C.-G.; Tsao, K.-C.; Lin, C.-S.; Chung, T.-Y.; Lai, C.-C.; Yang, C.-T.; et al. A hospital cluster of COVID-19 associated with a SARS-CoV-2 superspreading event. J. Microbiol. Immunol. Infect. 2021. [CrossRef]

26. Pérez-Lago, L.; Martínez-Lozano, H.; Pajares-Díaz, J.A.; Díaz-Gómez, A.; Machado, M.; Sola-Campoy, P.J.; Herranz, M.; Valerio, M.; Olmedo, M.; Suárez-González, J.; et al. Overlapping of Independent SARS-CoV-2 Nosocomial Transmissions in a Complex Outbreak. mSphere 2021, 6, e0038921. [CrossRef]

27. Arnedo-Pena, A.; Sabater-Vidal, S.; Meseguer-Ferrer, N.; Pac-Sa, M.R.; Mañes-Flor, P.; Gascó-Laborda, J.C.; Larrea, R.M.; TiradoBalaguer, M.D.; Romeu-García, M.Á.; Gil-Fortuño, M.; et al. COVID-19 secondary attack rate and risk factors in household contacts in Castellon (Spain): Preliminary report. Enferm. Emerg. 2020, 19, 64-70.

28. Méndez-Echevarría, A.; Sainz, T.; de Felipe, B.; Alcolea, S.; Olbrich, P.; Goycochea-Valdivia, W.A.; Escosa-García, L.; Cobo, L.; Calvo, C.; Neth, O. High Rates of SARS-CoV-2 Family Transmission in Children of Healthcare Workers during the First Pandemic Wave in Madrid, Spain: Serologic Study. Pediatr. Infect. Dis. J. 2021, 40, e185-e188. [CrossRef] [PubMed]

29. Sabetian, G.; Moghadami, M.; Hashemizadeh Fard Haghighi, L.; Shahriarirad, R.; Fallahi, M.J.; Asmarian, N.; Moeini, Y.S COVID-19 infection among healthcare workers: A cross-sectional study in southwest Iran. Virol. J. 2021, 18, 58. [CrossRef] [PubMed]

30. Wang, X.; Zhou, Q.; He, Y.; Liu, L.; Ma, X.; Wei, X.; Jiang, N.; Liang, L.; Zheng, Y.; Ma, L.; et al. Nosocomial outbreak of COVID-19 pneumonia in Wuhan, China. Eur. Respir. J. 2020, 55, 2000544. [CrossRef] [PubMed]

31. Koopsen, J.; Dekker, M.; Thung, P.; Jonges, M.; Vennema, H.; Leenstra, T.; Eggink, D.; Welkers, M.R.A.; Struijs, P.A.A.; Reusken, C.; et al. Rapid reinfection with SARS-CoV-2 variant-of-concern Alpha detected in a nurse during an outbreak at a non-COVID inpatient ward: Lessons learned. Antimicrob. Resist. Infect. Control 2021, 10, 137. [CrossRef]

32. Abbas, M.; Robalo Nunes, T.; Martischang, R.; Zingg, W.; Iten, A.; Pittet, D.; Harbarth, S. Nosocomial transmission and outbreaks of coronavirus disease 2019: The need to protect both patients and healthcare workers. Antimicrob. Resist. Infect. Control 2021, 10, 7. [CrossRef]

33. Vimercati, L.; Tafuri, S.; Chironna, M.; Loconsole, D.; Fucilli, F.I.M.; Migliore, G.; Gesualdo, L. The COVID-19 hotel for healthcare workers: An Italian best practice. J. Hosp. Infect. 2020, 105, 387-388. [CrossRef]

34. Shin, H.; Sharma, A.; Nicolau, J.L.; Kang, J. The impact of hotel CSR for strategic philanthropy on booking behavior and hotel performance during the COVID-19 pandemic. Tour. Manag. 2021, 85, 104322. [CrossRef]

35. Teng, X.; Teng, Y.-M.; Wu, K.-S.; Chang, B.-G. Corporate Social Responsibility in Public Health during the COVID-19 Pandemic: Quarantine Hotel in China. Front. Public Health 2021, 9, 620930. [CrossRef] [PubMed]

36. Jordan-Martin, N.C.; Madad, S.; Alves, L.; Wang, J.; O'Gere, L.; Smith, Y.G.; Pressman, M.; Shure, J.A.; Cosmi, M. Isolation Hotels: A Community-Based Intervention to Mitigate the Spread of the COVID-19 Pandemic. Health Secur. 2020, 18, 377-382. [CrossRef] [PubMed]

37. Chersich, M.F.; Gray, G.; Fairlie, L.; Eichbaum, Q.; Mayhew, S.; Allwood, B.; English, R.; Scorgie, F.; Luchters, S.; Simpson, G.; et al. COVID-19 in Africa: Care and protection for frontline healthcare workers. Glob. Health 2020, 16, 46. [CrossRef]

38. Gürlek, M.; Kılıç, İ. A true friend becomes apparent on a rainy day: Corporate social responsibility practices of top hotels during the COVID-19 pandemic. Curr. Issues Tour. 2021, 24, 905-918. [CrossRef]

39. Public Health England. Understanding the Impact of COVID-19 on BAM; PHE: London, UK, 2020.

40. Denford, S.; Morton, K.; Horwood, J.; de Garang, R.; Yardley, L. Preventing within household transmission of COVID-19: Is the provision of accommodation to support self-isolation feasible and acceptable? BMC Public Health 2021, 21, 1641. [CrossRef] [PubMed] 
41. Gobierno de España. Ley 14/1986, de 25 de abril, General de Sanidad. Boletín Of. Del Estado 1986, 102, 15207-15224.

42. Gobierno de España. Ley 16/2003, de 28 de mayo, de cohesión y calidad del Sistema Nacional de Salud. Boletín Of. Del Estado 2003, 128, 20567-20588.

43. Gobierno de España. Ley 33/2011, de 4 de octubre, General de Salud Pública. Boletín Of. Del Estado 2011, 10240, $104593-104626$.

44. Gobierno de España. Ley 2/2021, de 29 de marzo, de medidas urgentes de prevención, contención y coordinación para hacer frente a la crisis sanitaria ocasionada por el COVID-19. Boletín Of. Del Estado 2020, 76, 35952-35980.

45. Código de Vigilancia Epidemiológica; Agencia Estatal Boletín Oficial del Estado: Madrid, Spain, 2021. Available online: https: / / www.boe.es/biblioteca_juridica/codigos / codigo.php?id=352_Codigo_de_Vigilancia_Epidemiologica\&modo=2 (accessed on 13 November 2021).

46. Consejo Interterritorial del Sistema Nacional de Salud. Plan de Respuesta Temprana en un Escenario de Control de la Pandemia por el COVID-19; Ministerio de Sanidad: Madrid, Spain, 2020.

47. COVID-19: Derecho Europeo y Estatal; Agencia Estatal Boletín Oficial del Estado: Madrid, Spain, 2021. Available online: https: / / boe.es / biblioteca_juridica / codigos / codigo.php?id=355_Crisis_Sanitaria_COVID-19\&tipo=C\&modo=2 (accessed on 13 November 2021). 